\title{
IBM PENELITIAN TINDAKAN KELAS GURU SD NEGERI 101868 DAN SDN 105323 DESA BAKARAN BATU KABUPATEN DELI SERDANG MELALUI PENDAMPINGAN PENGEMBANGAN KEPROFESIAN BERKELANJUTAN
}

\author{
Ely Djulia, Halim Simatupang, Nurhairani, Amrizal \\ Surel : halimsimatupang@yahoo.co.id
}

\begin{abstract}
This study was conducted by delivering 8-day action research workshop, followed up by mentoring into each group during teacher doing action research focusing on designing action research proposal, wrting their action research report, and wrting report into scientific article, facilitating teacher to publish their article into journal at LPM Unimed or journal with ISSN.This study was conducted at two partner schools: SD Negeri 101868 Desa Sena Kecamatan Batang Kuis and SD Negeri 105323 Desa Bakaran Batu Kecamatan Batang Kuis Kabupaten Deli Serdang. The outcome of this IbM is Primary teachers understand principle and procedure of action research, teachers are able to design and write action research proposal, conduct action research, from planning, action, observation, until reflection, reporting result of action research and publish them into scientific journal. The output of this IbM is product of action research reports and scientific articles, hopefully they can be published.
\end{abstract}

Key Word: Action Research Workshop, Teaching Learning Innovation

\begin{abstract}
ABSTRAK
Metode pelatihan ini dilakukan dengan memberikan pelatihan PTK, mendampingi guru-guru melaksanakan PTK, menyusun laporan PTK, membuat hasil penelitian menjadi artikel ilmiah, dan memfasilitasi guru-guru untuk menerbitkan artikel ilmiahnya pada jurnal pengabdian edisi khusus LPM Unimed atau jurnal ber ISSN.Kegiatan ini dilaksanakan di Mitra 1 SD Negeri 101868 Desa Sena Kecamatan Batang Kuis dan Mitra 2 SD Negeri 105323 Desa Bakaran Batu Kecamatan Batang Kuis Kabupaten Deli Serdang. Capaian kegiatan $\mathrm{I}_{\mathrm{b}} \mathrm{M}$ ini adalah guru-guru memahami prinsip dan prosedur PTK, guru-guru mampu merancang dan menulis proposal PTK, guru-guru mampu melakukan PTK dari tahap perencanaan, pelaksanaan, observasi, sampai dengan refleksi, dan guruguru mampu menyajikan hasil PTK dalam bentuk laporan penelitian dan jurnal ilmiah. Adapun luaran dari kegiatan ini adalah menghasilkan produk berupa laporan penelitian tindakan kelas dan artikel ilmiah, dimana diharapkan minimal $10 \%$ karya ilmiah yang dihasilkan dapat diterbitkan.
\end{abstract}

Kata Kunci : Pelatihan PTK, Inovasi Pembelajaran

\section{PENDAHULUAN}

Mitra 1 SD Negeri 101868

Desa Sena, merupakan sekolah dasar yang terletak di Kecamatan Batang Kuis Kabupaten Deli Serdang.
Sekolah ini berada di pinggir jalan dan memiliki lokasi yang strategis untuk dikases oleh masyarakat. Jumlah ruangan di SD ini berjumlah 8 ruangan dengan jumlah siswa 339

Dosen Universitas Negeri Medan 

orang dan jumlah guru disekolah ini berjumlah 16 dan pegawai berjumlah 2 orang, sekolah ini juga memiliki musholah sebagai tempat aktifitas siswa dan dibelakang sekolah ini juga terdapat lapangan yang selalu digunakan untuk aktifitas perkemahan pramuka di Kecamatan Batang Kuis dan pembinaan Olahraga.

SD Negeri 101868 Desa Sena Kabupaten Deli Serdang, diidentifikasi masalah yang dihadapi calon mitra yaitu masih rendahnya kualitas pembelajaran yang dilakukan guru dan masih rendahnya golongan yang dimiliki oleh guru, karena guru tidak bisa naik golongan kalau tidak memiliki karya tulis ilmiah. Dari 16 guru yang ada disekolah, 15 orang guru sudah menyelesaikan S-1 dan 1 orang tamatan SPG. Guru yang bergolongan IV berjumlah 5 orang, yang bergolongan III berjumlah 8 orang, dan guru honor berjumlah 3 orang, semua guru belum ada yang mengusulkan kenaikan golongan karena tidak memiliki karya ilmiah berupa PTK. Setelah melakukan diskusi dengan kepala sekolah dan guru maka diambillah suatu kesepakatan persoalan yang paling mendesak untuk segera diselesaikan adalah membantu guru untuk bisa dan mampu menyusun proposal Penelitian Tindakan Kelas (PTK) sehingga diharapkan guru bisa mengevaluasi pembelajaran yang dilakukannya dan sekaligus membantu guru untuk mengusulkan kenaikan pangkat.
Mitra 2 SD Negeri 105323 Desa Bakaran Batu Kabupaten Deli Serdang, merupakan sekolah dasar yang terletak di sebuah pedesaan yang masih asri. Sekolah ini berada di lingkungan masyarakat dan memiliki lokasi yang strategis untuk diakses oleh masyarakat. Jumlah ruangan di SD ini berjumlah 6 ruangan dengan jumlah siswa 390 orang dan jumlah guru disekolah ini berjumlah 18 orang dan pegawai berjumlah 1 orang. Sekolah dilaksanakan pagi dan sore. Kelas yang sekolah dipagi hari yaitu kelas 1, kelas 2, kelas 5 dan kelas 6, sementara kelas 3 dan kelas 4 masuk sore hari. SD Negeri 105323 Desa Bakaran Batu Kabupaten Deli Serdang, masih memiliki banyak masalah dalam pembelajaran, diidentifikasi masalah yang dihadapi calon mitra yaitu masih rendahnya kualitas pembelajaran yang dilakukan guru terutama dalam melakukan inovasi terhadap pembelajaran. Guru masih melakukan proses pembelajaran secara monoton dan masih sedikit menggunakan media dalam pembelajaran. Penulis juga melakukan pengamatan langsung kepada guru dalam mengajar. Dari pengamatan penulis masih banyak metode dan cara mengajar guru yang harus diperbaiki.

Guru-guru di SD Negeri 105323 belum ada yang mengurus kenaikan golongan, karena tidak memiliki kemampuan membuat Karya Tulis Ilmiah berupa PTK. Dari wawancara dengan guru dapat diketahui bahwa 
Para guru memiliki pemahaman yang lemah dalam pembuatan karya tulis ilmiah, khususnya mengenai PTK. Bahkan sebagian besar dari mereka tidak pernah melakukan PTK. Para guru menganggap melakukan PTK adalah pekerjaan yang sangat rumit dan sulit, hal ini mereka nyatakan berdasarkan pengalaman mereka mengerjakan skripsi ketika kuliah. Setelah melakukan diskusi dengan guru dan kepala sekolah, akhirnya diambillah kesepakatan bahwa yang sangat dibutuhkan oleh guru-guru adalah meningkatkan kemampuan mereka dalam melakukan inovasi dalam pembelajaran dengan melaksanakan Penelitian Tindakan Kelas.

Pendidikan yang bermutu sangat tergantung pada kapasitas satuansatuan pendidikan dalam mentranformasikan peserta didik untuk memperoleh nilai tambah, baik yang terkait dengan aspek olah pikir, rasa, hati, dan raganya.Dari sekian banyak komponen pendidikan, guru merupakan faktor yang sangat penting dan strategis dalam usaha meningkatkan mutu pendidikan di setiap satuan pendidikan. Berapa pun besarnya investasi yang ditanamkan untuk memperbaiki mutu pendidikan, tanpa kehadiran guru yang kompeten, profesional, bermartabat, dan sejahtera dapat dipastikan tidak akan tercapai tujuan yang diharapkan [UU No.14 Thn 2005:2].

\section{METODE PENELITIAN}

Metode pelaksanaan yang ditawarkan kepada mitra untuk mengatasi permasalahan yang dihadapi mitra adalah metode pendidikan, pelatihan serta pendampingan.

Berdasarkan analisis situasi mitra dapat diidentifikasikan permasalahannya yaiu pada mitra 1 sebagai berikut :

a. Dari Hasil survey pertama (7 Februari 2015) di SD Negeri 101868 Desa Sena, merupakan sekolah dasar yang terletak di Kecamatan Batang Kuis Kabupaten Deli Serdang. Sekolah ini berada di pinggir jalan dan memiliki lokasi yang strategis untuk dikases oleh masyarakat. Jumlah ruangan di SD ini berjumlah 8 rungan dengan jumlah siswa 339 orang dan jumlah guru disekolah ini berjumlah 16 dan pegawai berjumlah 2 orang, sekolah ini juga memiliki musholah sebagai tempat aktifitas siswa dan dibelakang sekolah ini juga terdapat lapangan yang selalu digunakan untuk aktifitas perkemahan pramuka di Kecamatan Batang Kuis dan pembinaan Olahraga.

b. Hasil Hasil survey kedua (14 Februari 2015) di SD Negeri 101868 Desa Sena Kabupaten Deli Serdang, diidentifikasi masalah yang dihadapi calon mitra yaitu masih rendahnya kualitas pembelajaran yang dilakukan guru dan masih 
rendahnya golongan yang dimiliki oleh guru, karena guru tidak bisa naik golongan kalau tidak memiliki karya tulis ilmiah. Dari 16 guru yang ada disekolah, 15 orang guru sudah menyelesaikan S-1 dan 1 orang tamatan SPG. Guru yang bergolongan IV berjumlah 5 orang, yang bergolongan III berjumlah 8 orang, dan guru honor berjumlah 3 orang, semua guru belum ada yang mengusulkan kenaikan golongan karena tidak memiliki karya ilmiah berupa PTK. Setelah melakukan diskusi dengan kepala sekolah dan guru maka diambillah suatu kesepakatan persoalan yang paling mendesak untuk segera diselesaikan adalah membantu guru untuk bisa dan mampu menyusun proposal Penelitian Tindakan Kelas (PTK) sehingga diharapkan guru bisa mengevaluasi pembelajaran yang dilakukannya dan sekaligus membantu guru untuk mengusulkan kenaikan pangkat.

\section{Berdasarkan analisis situasi mitra dapat diidentifikasikan permasalahannya yaiu pada mitra 2 sebagai berikut :}

a. Survey penulis pada tanggal 14 Februari 2015 di SD Negeri 105323 Desa Bakaran Batu Kabupaten Deli Serdang, merupakan sekolah dasar yang terletak di sebuah pedesaan yang masih asri. Sekolah ini berada di lingkungan masyarakat dan memiliki lokasi yang strategis untuk diakses oleh masyarakat. Jumlah ruangan di SD ini berjumlah 6 ruangan dengan jumlah siswa 390 orang dan jumlah guru disekolah ini berjumlah 18 orang dan pegawai berjumlah 1 orang. Sekolah melaksanakan pagi dan sore. Kelas yang sekolah dipafi hari yaitu kelas 1, kelas 2, kelas 5 dan kelas 6, sementara kelas 3 dan kelas 4 masuk sore hari. SD Negeri 105323 Desa Bakaran Batu Kabupaten Deli Serdang, masih memiliki banyak masalah dalam pembelajaran, diidentifikasi masalah yang dihadapi calon mitra yaitu masih rendahnya kualitas pembelajaran yang dilakukan guru terutama dalam melakukan inovasi terhadap pembelajaran. Guru masih melakukan proses pembelajaran secara monoton dan masih sedikit menggunakan media dalam pembelajaran. Penulis juga melakukan pengamatan langsung kepada guru dalam mengajar. Dari pengamatan penulis masih banyak metode dan cara mengajar guru yang harus diperbaiki.

b. Guru-guru di SD Negeri 105323 belum ada yang mengurus kenaikan golongan, karena tidak memiliki kemampuan membuat Karya Tulis Ilmiah berupa PTK. Dari wawancara dengan guru dapat diketahui bahwa Para guru 
b. Menetapkan jumlah peserta pelatihan sebanyak 25 orang guru dan menetapkan lokasi pelatihan, kemudian melaksanakan pelatihan.

c. Pelaksanaan kegiatan pelatihan dengan kerangka acuan kegiatan PTK: Setiap peserta mendapat informasi tentang, a) Pengantar Penelitian Tindakan Kelas (PTK), b) Metodologi Penelitian Tindakan Kelas (PTK), c) Teknik penyusunan proposal PTK, d) Sharing experience tentang PTK, e) Pembimbingan penyusunan proposal PTK. Workshop ini berbentuk penyampaian materi, diskusi, dan pembimbingan pembuatan PTK kepada peserta workshop. Peserta dibimbing sampai bisa menghasilkan PTK sendiri. Target kegiatan ini adalah setiap peserta dapat membuat Penelitian Tindakan Kelas yang nantinya dapat diajukan sebagai portofolio untuk sertifikasi guru,kenaikan pangkat atau kegiatan ilmiah lainnya

d. Setelah selesai mendapatkan informasi dari narasumber dilanjutkan dengan action plan dengan melakukan aktivitas menyusun proposal PTK.

e. Kegiatan Bimbingan dan Pendampingan: kegiatan action plan dibimbing oleh seorang narasumber untuk 8-9 orang guru, selanjutnya hasil kegiatan action plan didiskusikan dan selanjutnya disimulasikan dalam kegiatan peer teaching dan supervise klinis.

f. Evaluasi dan Monitoring : dilakukan presentasi untuk mengetahui progress report dan mengetahui pemahaman peserta terhadap PTK.

g. Pelaporan.

\section{HASIL PENELITIAN DAN PEMBAHASAN}

Pada tahap ini hasil yang diperoleh adalah kesediaan mitra kerja (pihak sekolah) untuk mengikuti Pelatihan Penelitian Tindakan Kelas (PTK) untuk meningkatan Profesionalisme GuruGuru SD di Kabupaten Deli Serdang. Adapun mitra kerja yang turut serta dalam pelatihan ini adalah SDN 101868 Desa Sena, SDN 105323 Desa Bakaran Batu.

Dalam kegiatan pelatihan ini, keberlangsungan kerja sama tetap terjalin dengan adanya pelatihan dan pendampingan PTK berkelanjutan selama kurun waktu lebih kurang 5 bulan dimana masing-masing mitra kerja mengirimkan guru-guru yang membutuhkan pelatihan PTK untuk memenuhi kebutuhan kenaikan pangkat dan fungsional.

Tabel pencapaian Indikator

\begin{tabular}{|c|l|l|l|}
\hline No & $\begin{array}{l}\text { Aplikasi } \\
\text { Kegiatan }\end{array}$ & $\begin{array}{l}\text { Metode } \\
\text { Pendekatan }\end{array}$ & Capaian \\
\hline 1. & $\begin{array}{l}\text { Persiapan } \\
\text { kegiatan } \\
\text { meliputi }\end{array}$ & $\begin{array}{l}\text { Rapat dan } \\
\text { Kordinasi }\end{array}$ & $\begin{array}{l}\text { Terbentu } \\
\text { knya } \\
\text { Tim dan } \\
\end{array}$ \\
$\begin{array}{l}\text { Pembentuka } \\
\text { n Tim } \\
\text { Pelaksana, } \\
\text { rapat }\end{array}$ & & $\begin{array}{l}\text { terjalinn } \\
\text { ya } \\
\text { komunik } \\
\text { asi }\end{array}$ \\
\hline
\end{tabular}


Ely Djulia, Halim Simatupang, Nurhairani

\begin{tabular}{|c|c|c|c|}
\hline & $\begin{array}{l}\text { koordinasi } \\
\text { dengan } \\
\text { lembaga } \\
\text { terkait. }\end{array}$ & & $\begin{array}{l}\text { dengan } \\
\text { LPM } \\
\text { Unimed } \\
\text { dan } \\
\text { Sekolah. }\end{array}$ \\
\hline 2 & $\begin{array}{l}\text { Pembuatan } \\
\text { modul dan } \\
\text { publikasi. }\end{array}$ & $\begin{array}{l}\text { Penyusunan } \\
\text { Modul }\end{array}$ & $\begin{array}{l}\text { Tersusun } \\
\text { nya } \\
\text { Modul } \\
\text { Pelatihan } \\
\text { PTK } \\
\text { IbM } \\
\text { Guru SD } \\
\text { sebagai } \\
\text { panduan } \\
\text { dalam } \\
\text { pelaksan } \\
\text { aan } \\
\text { pelatihan }\end{array}$ \\
\hline 3 & $\begin{array}{l}\text { Menetapkan } \\
\text { jumlah } \\
\text { peserta } \\
\text { pelatihan dan } \\
\text { menetapkan } \\
\text { lokasi } \\
\text { pelatihan, } \\
\text { kemudian } \\
\text { melaksanaka } \\
\text { n pelatihan }\end{array}$ & $\begin{array}{l}\text { Melakukan } \\
\text { Kunjungan } \\
\text { dan } \\
\text { koordinasi } \\
\text { ke Sekolah } \\
\text { Mitra }\end{array}$ & $\begin{array}{l}\text { Ditetapk } \\
\text { annya } \\
\text { jadwal } \\
\text { pelatihan } \\
\text { dan } \\
\text { peserta } \\
\text { yang } \\
\text { akan } \\
\text { mengikut } \\
\text { i } \\
\text { pelatihan } \\
\text { Jumlah } \\
\text { guru } \\
\text { yang } \\
\text { akan } \\
\text { mengikut } \\
\text { i } \\
\text { pelatihan } \\
\text { berjumla } \\
\text { h } 20 \\
\text { orang } \\
\text { yang } \\
\text { berasal } \\
\text { dari 2 } \\
\text { sekolah } \\
\text { yaitu SD } \\
\text { Negeri } \\
101868 \\
\text { sebanyak } \\
11 \text { orang } \\
\text { dan SD } \\
\text { Negeri } \\
105323 \\
\text { sebanyak } \\
9 \text { orang. }\end{array}$ \\
\hline 4 & $\begin{array}{l}\text { Menyelengg } \\
\text { arakan } \\
\text { workshop } \\
\text { Pengenalan } \\
\text { PTK dan } \\
\text { KTI }\end{array}$ & $\begin{array}{l}\text { Pelatihan } \\
\text { dan } \\
\text { Workshop }\end{array}$ & $\begin{array}{l}\text { Guru } \\
\text { mengeta } \\
\text { hui kiat } \\
\text { dan cara } \\
\text { menyusu } \\
\text { n } \\
\text { proposal } \\
\text { PTK dan }\end{array}$ \\
\hline
\end{tabular}

\begin{tabular}{|c|c|c|c|}
\hline & & & KTI. \\
\hline 5 & $\begin{array}{l}\text { Workshop } \\
\text { Menyusun } \\
\text { Proposal } \\
\text { PTK }\end{array}$ & Pelatihan & $\begin{array}{l}\text { Guru } \\
\text { Menyusu } \\
\mathrm{n} \\
\text { proposal } \\
\text { PTK, } \\
\text { dimulai } \\
\text { dari } \\
\text { menemu } \\
\text { kan } \\
\text { masalah, } \\
\text { membuat } \\
\text { judul, } \\
\text { menyusu } \\
\text { n BAB I, } \\
\text { II dan } \\
\text { III. }\end{array}$ \\
\hline 6 & $\begin{array}{l}\text { Melakukan } \\
\text { pendampinga } \\
\text { n dalam } \\
\text { Penyusunan } \\
\text { Proposal } \\
\text { PTK }\end{array}$ & $\begin{array}{l}\text { Pendamping } \\
\text { an }\end{array}$ & $\begin{array}{l}\text { Guru } \\
\text { Berlatih } \\
\text { Menyusu } \\
\mathrm{n} \\
\text { proposal } \\
\text { PTK } \\
\text { mulai } \\
\text { dari } \\
\text { BAB I, II } \\
\text { dan III. }\end{array}$ \\
\hline 7 & $\begin{array}{l}\text { Pengambilan } \\
\text { Data }\end{array}$ & $\begin{array}{l}\text { Pendamping } \\
\text { an }\end{array}$ & $\begin{array}{l}\text { Mendam } \\
\text { pingi } \\
\text { guru } \\
\text { dalam } \\
\text { mengam } \\
\text { bil data } \\
\text { penelitia } \\
\text { n } \\
\text { tindakan } \\
\text { kelas di } \\
\text { sekolah }\end{array}$ \\
\hline 8 & $\begin{array}{l}\text { Pengolahan } \\
\text { Data }\end{array}$ & $\begin{array}{l}\text { Pendamping } \\
\text { an }\end{array}$ & $\begin{array}{l}\text { Mendam } \\
\text { pingi } \\
\text { guru } \\
\text { dalam } \\
\text { melakuk } \\
\text { an } \\
\text { pengolah } \\
\text { an data } \\
\text { penelitia } \\
\text { n } \\
\text { tindakan } \\
\text { kelas. }\end{array}$ \\
\hline 9 & $\begin{array}{l}\text { Melakukan } \\
\text { Pendamping } \\
\text { an } \\
\text { Menyusun } \\
\text { Laporan } \\
\text { PTK }\end{array}$ & $\begin{array}{l}\text { Pendamping } \\
\text { an }\end{array}$ & $\begin{array}{l}\text { Guru } \\
\text { Berlatih } \\
\text { Menyusu } \\
\mathrm{n} \\
\text { Laporan } \\
\text { PTK }\end{array}$ \\
\hline 10 & $\begin{array}{l}\text { Menyelengg } \\
\text { arakan } \\
\text { seminar hasil }\end{array}$ & Seminar & $\begin{array}{l}\text { Guru } \\
\text { memapar } \\
\text { kan hasil }\end{array}$ \\
\hline
\end{tabular}




\begin{tabular}{|c|c|c|c|}
\hline & $\begin{array}{l}\text { PTK } \\
\end{array}$ & & $\begin{array}{l}\text { penelitia } \\
\text { n PTK }\end{array}$ \\
\hline 11 & \begin{tabular}{ll}
\multicolumn{2}{l}{ Workshop } \\
\multicolumn{2}{l}{ Membuat } \\
karya & tulis \\
dari & hasil \\
PTK &
\end{tabular} & Pelatihan & $\begin{array}{l}\text { Guru } \\
\text { Membua } \\
\mathrm{t} \text { karya } \\
\text { tulis } \\
\text { untuk } \\
\text { dimasuk } \\
\text { kan ke } \\
\text { jurnal. } \\
\text { Jurnal } \\
\text { yang } \\
\text { menjadi } \\
\text { mitra } \\
\text { IbM } \\
\text { yaitu } \\
\text { Jurnal } \\
\text { PENA } \\
\text { dengan } \\
\text { nomor } \\
\text { ISSN : } \\
\text { 2528- } \\
\text { 0007 }\end{array}$ \\
\hline 12 & $\begin{array}{l}\text { Mendamping } \\
\mathrm{i} \text { guru } \\
\text { membuat } \\
\text { laporan dan } \\
\text { bahan } \\
\text { publikasi }\end{array}$ & $\begin{array}{l}\text { Pendamping } \\
\text { an }\end{array}$ & $\begin{array}{l}\text { Guru } \\
\text { mempubl } \\
\text { ikasi } \\
\text { hasil } \\
\text { PTK }\end{array}$ \\
\hline 13 & $\begin{array}{l}\text { Menyusun } \\
\text { Laporan } \\
\text { Kegiatan } \\
\text { IbM }\end{array}$ & $\begin{array}{l}\text { Mengumpulk } \\
\text { an data } \\
\text { kegiatan }\end{array}$ & $\begin{array}{l}\text { Tersusun } \\
\text { nya } \\
\text { laporan } \\
\text { kegiatan } \\
\text { IbM }\end{array}$ \\
\hline
\end{tabular}

\section{Pembahasan}

Sesuai dengan target dari kegiatan ini yaitu dimulai dari pemaparan tentang PTK, pelatihan penulisan proposal PTK dilanjut dengan pelaksanaan di kelas masing-masing guru sampai akhirnya diperoleh data. Setelah itu guru-guru melakukan pengolahan data dan menyusun laporan akhir dari PTK mereka masing-masing secara lengkap.Berdasarkan laporan akhir guru-guru tersebut, mereka dibimbing kembali untuk membuat artikel sebagai karya ilmiahnya untuk diterbitkan dalam jurnal khusus bagi guru-guru.Sejauh ini terdapat kendala yaitu sebagian besar guru-guru tersebut tidak mnguasai ICT (tidak mampu menggunakan komputer), sehingga mereka tersendat pada penulisan proposal dan laporan akhir.Sebagai jalan keluar, mereka meminta pertolongan keluarga masingmasing yang mampu menggunakan komputer.

\section{Capaian kegiatan dapat dilihat pada Tabel dibawah ini}

\begin{tabular}{|c|c|c|c|c|}
\hline $\begin{array}{l}\text { Indikator } \\
\text { kerja }\end{array}$ & $\begin{array}{l}\text { Base } \\
\text { Line }\end{array}$ & Target & Capaian & $\begin{array}{l}\text { Persentase } \\
\text { Capaian }\end{array}$ \\
\hline $\begin{array}{l}\text { Peningka } \\
\text { tan } \\
\text { kemampu } \\
\text { an guru } \\
\text { dalam } \\
\text { Penelitia } \\
\text { n } \\
\text { tindakan } \\
\text { kelas(PT } \\
\mathrm{K})\end{array}$ & $\begin{array}{l}\text { Blm } \\
\text { ada }\end{array}$ & ada & ada & $100 \%$ \\
\hline $\begin{array}{l}\text { Penulisan } \\
\text { Laporan } \\
\text { PTK dan } \\
\text { karya } \\
\text { ilmiah } \\
\text { dari hasil } \\
\text { PTK } \\
\text { yang } \\
\text { telah } \\
\text { dilaksana } \\
\text { kan guru }\end{array}$ & $\begin{array}{l}\text { Belu } \\
\text { m } \\
\text { ada }\end{array}$ & ada & ada & $60 \%$ \\
\hline $\begin{array}{l}\text { Penerbita } \\
\text { n jurnal } \\
\text { dari PKI* } \\
\text { yang } \\
\text { telah } \\
\text { dihasilka } \\
\text { n }\end{array}$ & $\begin{array}{l}\text { Belu } \\
\mathrm{m} \\
\text { ada }\end{array}$ & ada & ada & $20 \%$ \\
\hline
\end{tabular}

*PKI yang dihasilkan berasal dari guru yang telah membuat laporan PTK 
Ely Djulia, Halim Simatupang, Nurhairani ....

SIMPULAN

Kesimpulan yang didapatkan dari pelaksanaan kegiatan IbM Guru SD ini adalah :

a. Pelaksanaan kegiatan sudah berjalan dengan baik dan lancar, hal ini dapat dilihat dari hasil capaian guru dalam menyusun proposal dan Laporan PTK.

b. Motivasi menulis guru-guru masih rendah, hal ini mungkin disebabkan pengetahuan mereka yang minim dan tidak adanya kemampuan dalam hal penguasaan ICT

c. Proses pembelajaran yang dilakukan guru dikelas masih monoton dan kurang inovasi.

d. Guru-guru juga belum mengenal model-model pembelajaran yang berkembang sebagai alat bantu untuk menyelesaikan masalah pembelajaran.

e. Laporan PTK yang dibuat oleh guru sudah memenuhi standar sesuai UU yang berlaku dan bisa membantu kenaikan pangkat guru.

\section{DAFTAR RUJUKAN}

Andreas, 2001. PetunjukPraktis Classroom Base Action Researh. Semarang:
Kanwil Depdiknas, Propinsi Jawa Tengah. Anonim. 1999. Penelitian Tindakan Kelas. Jakarta: Dirjen Dikti

Sani, R.A. 2013. Meningkatkan Profesionalisme Guru Melalui Penelitian Tindakan Kelas. Bandung: Cita Pustaka.

Sani, R.A. 2013. Inovasi Pembelajaran. Jakarta: Bumi Aksara.

Sudjana, Nana. 2003. Penelitian dan Penilaian Pendidikan. Bandung: Sinar Baru Offset.

Suharsimi, dkk. 2008. Penelitian Tindakan Kelas. Jakarta. Bumi Aksara

Suhardjono, Azis Hoesein, dkk. 1996. Pedoman Penyusunan Karya Tulis Ilmiah di Bidang Pendidikan dan Angka Kredit Pengembangan Profesi Guru. Jakarta: Depdikbud, Dikdas.

Sukidin. 2004. Management Penelitian Tindakan Kelas. Jakarta. Intan Cendikia

Wibowo, M.E. 2007. Panduan Penulisan Karya Ilmiah. Semarang: Unnes Press. Zainal Aqib, 2006. Penelitian Tindakan Kelas Untuk Guru. Bandung: Yrama Widya 